\title{
Sesquiterpene Lactones from Centaurea achaia, a Greek Endemic Species: Antifungal Activity
}

\author{
Helen Skaltsa ${ }^{\mathrm{a}, *}$, Diamanto Lazari ${ }^{\mathrm{a}}$, Begoña Garciab ${ }^{\mathrm{b}}$, José R. Pedro ${ }^{\mathrm{b}}$, \\ Marina Sokovic ${ }^{\mathrm{c}}$ and Theophanis Constantinidis ${ }^{\mathrm{d}}$ \\ a Department of Pharmacognosy, School of Pharmacy, University of Athens, \\ Panepistimiopolis, Zografou, GR-15771 Athens, Greece. Fax: +301-8613965. \\ E-mail: skaltsa@pharm.uoa.gr \\ b Department of Organic Chemistry, Faculty of Chemistry, University of Valencia, \\ 46100-Burjassot, Valencia, Spain \\ c Department of Plant Physiology, Mycological Laboratory, Institute for \\ Biological Research, 29 Novembar 142, 11000 Belgrade, Yugoslavia \\ d Botanical Institute, Department of Biology, University of Patras, GR-26 500 Patras, Greece \\ * Author for correspondence and reprint requests \\ Z. Naturforsch. 55c, 534-539 (2000); received March 27/April 28, 2000 \\ Centaurea achaia, Sesquiterpene Lactones, Antifungal Activity \\ The aerial parts of Centaurea achaia afforded, in addition to several known sesquiterpene \\ lactones and sesquiterpene hydroxyesters, a new germacranolide and a new elemanolide. \\ Their structures were determined as the $8 \alpha$-O-(4,5-dihydroxy-tigloyloxy) esters of saloniteno- \\ lide and of 11,13-dihydromelitensin, respectively. The in vitro antifungal activity of most \\ compounds was tested against nine fungal species using the micro-dilution method. All the \\ tested compounds showed strong antifungal activity.
}

\section{Introduction}

The large genus Centaurea (Asteraceae - Cardueae) comprises about 500 species, which are predominately distributed around the Mediterranean area and in W Asia (Mabberley, 1997). Continuing our research on the chemical constituents of Centaurea sp. (Skaltsa et al., 1999; Cardona et al., 1997), we have investigated C. achaia, a greek endemic taxon, belonging to the section Acrocentron (Cass.) D. C.

We now report the isolation of nine germacranolides (1-9), two elemanolides $(\mathbf{1 0}, \mathbf{1 1})$, two eudesmanolides $(\mathbf{1 3}, \mathbf{1 4})$ and the hydroxyester derivatives $\mathbf{1 2}$ and $\mathbf{1 5}$. Compounds $\mathbf{7}$ and $\mathbf{1 1}$ are new naturally occurring sesquiterpene lactones and their structures were elucidated by extensive highfield NMR studies. Compounds 2-4, 7, 8, 10-15 were tested against several micromycetes.

\section{Results and Discussion}

Chromatographic separation of the ethyl acetate extract of $C$. achaia (aerial parts) yielded salonitenolide (1) (Cardona et al., 1997) and its $8 \alpha$-acyl derivatives onopordopicrin (2) (Cardona et al., 1989), 3 (El-Masry et al., 1985) 4 (El-Masry et al.,
1985), 5 (Lazari et al., 1998), 6 (Lazari et al., 1998) and the new compound 7; 11 $\beta, 13$-dihydrosalonitenolide (8) (Marco et al., 1992) and its acyl derivative 9 (Lazari et al., 1998); the dehydromelitensin derivative 10 (Cardona et al., 1989) and the new compound 11; elemacarmanin (12) (Cardona et al., 1989); the eudesmanolides 13 (Rustaiyan et al., 1986) and 14 (Rustaiyan et al., 1986); 4-epi-carmanin (15) (Rustayian et al., 1986). All compounds were isolated in sufficient amounts to allow structure elucidation (Fig. 1) and most of them were tested against several micromycetes. We also report the ${ }^{13} \mathrm{C}$ NMR for compound $\mathbf{1 5}$.

Compound 7 was identified as an $8 \alpha$-acyl derivative of salonitenolide, since its ${ }^{1} \mathrm{H}$ and ${ }^{13} \mathrm{C}$ NMR spectra were similar to those of compounds 1-6. Its molecular formula $\left(\mathrm{C}_{20} \mathrm{H}_{26} \mathrm{O}_{7}\right)$ was deduced from its IR, ${ }^{13} \mathrm{C}$ NMR, and EIMS spectral data. The IR spectrum afforded intense absorptions at 3600-3300 (OH), $1750(\mathrm{C}=\mathrm{O}, \gamma$-lactone $)$ and 1720 $\mathrm{cm}^{-1}(\mathrm{C}=\mathrm{O}$, ester $)$. The analysis of the ${ }^{13} \mathrm{C}$ NMR and DEPT experiments (Table I) indicated that 7 contained twenty carbons: one $\mathrm{CH}_{3}$, seven $\mathrm{CH}_{2}$ (one exomethylene, three hydroxymethyl and three highfield methylenes), six $\mathrm{CH}$ (three $\mathrm{sp}^{2}$ methines, two carbinols and a saturated methine), 


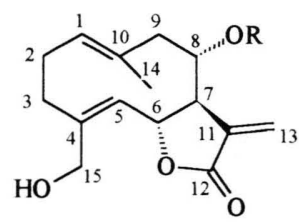

$1 \mathrm{R}=\mathrm{H}$

$2 \mathrm{R}=\mathrm{A}$

$3 \mathrm{R}=\mathrm{B}$

$4 \mathrm{R}=\mathrm{C}$

$5 \mathrm{R}=\mathrm{D}$

$6 \mathrm{R}=\mathrm{E}$

$7 \mathrm{R}=\mathrm{F}$<smiles>[R]O[C@H]1C[C@](C)(C=C)[C@H](C(=C)CO)[C@H](O)[C@H]1C(=C)C(=O)OC</smiles>

$12 \mathrm{R}=\mathrm{A}$

$A=$<smiles>CC(=O)C(C)CO</smiles>

$\mathrm{B}=$<smiles>CC=C(CO)C(C)=O</smiles><smiles>[R]O[C@H](C/C(C)=C/CC/C(=C\CO)CO)[C@H]1[C@@H](C)OC(=O)[C@@H]1C</smiles>

$8 \mathrm{R}=\mathrm{H}$

$9 \mathrm{R}=\mathrm{E}$<smiles>[R]O[C@H]1C[C@@](C)(C=C)[C@H](C(=C)CO)[C@@H]2OC(=O)C(=C)[C@H]12</smiles>

$10 \mathrm{R}=\mathrm{A}$

$11 \mathrm{R}=\mathrm{F}$<smiles>[R]O[C@H]1C[C@]2(C)[C@@H](O)CC[C@H](C=O)[C@H]2[C@H]2OC(=O)C(=C)[C@H]12</smiles>

$134 \alpha \mathrm{H}, \mathrm{R}=\mathrm{A}$

$144 \beta H, R=A$<smiles>C#CC(=O)/C(C)=C/CO</smiles>

$\mathrm{E}=$<smiles>[R]O[C@H]1C[C@]2(C)[C@@H](O)CC[C@H](C=O)[C@H]2[C@H](O)[C@@H]1C(=C)C(=O)OC</smiles>

$154 \beta H, R=A$

$\mathrm{D}=$<smiles>C=C(C)C(C)=O</smiles>

$\mathrm{F}=$<smiles>CC(=O)/C(=C/CO)CO</smiles>

Fig. 1. Structures of the isolated compounds. as well as four olefinic quaternary carbons and two carbonyls ( $\delta 167.5, \gamma$-lactone; $\delta 172.5$, ester). From those data a molecular formula $\mathrm{C}_{20} \mathrm{H}_{26} \mathrm{O}_{7}$ was suggested, which is in accordance with the peak at $\mathrm{m} / z, 378[\mathrm{M}]^{+}$in the mass spectrum. In its ${ }^{1} \mathrm{H}$ NMR spectrum (Table I) the broadened doublet at $\delta 4.97(J=8.7$ and $9.1 \mathrm{~Hz})$ and the broadened doublet at $\delta 4.81(J=9.5 \mathrm{~Hz})$ were assigned to $\mathrm{H}-1$ and $\mathrm{H}-5$, respectively. In the ${ }^{13} \mathrm{C}$ NMR spectra the signals at $\delta 131.1,145.7,130.1$ and 133.0 were assigned to C-1, C-4, C-5 and C-10, respectively. The chemical shifts of the methyl group $(s, \delta 1.48$ in the ${ }^{1} \mathrm{H}$ NMR, $\delta 17.4$ in the ${ }^{13} \mathrm{C}$ NMR) were the usual values for a $\mathrm{C}-10$ methyl group in germacranolides. From a pair of doublets at $\delta 4.28$ and 4.06 $(J=14.1 \mathrm{~Hz})$ a hydroxymethyl group (at $\delta 61.1$ in the ${ }^{13} \mathrm{C}$ NMR spectrum) as substituent at C-4 was evident. The presence of an oxygenated group at $\mathrm{C}-6 \alpha\left(\delta 78.9\right.$ in the ${ }^{13} \mathrm{C}$ NMR) was inferred from the double doublet at $\delta 4.99(J=7.9$ and $9.1 \mathrm{~Hz})$, 
Table I. ${ }^{1} \mathrm{H}$ NMR of compound $\mathbf{7}$ and $\mathbf{1 1}\left(400 \mathrm{MHz}, \mathrm{CDCl}_{3}\right)$ and ${ }^{13} \mathrm{C} \mathrm{NMR}$ of compound $7\left(50.3 \mathrm{MHz}, \mathrm{CD}_{3} \mathrm{OD}\right)$ and $15\left(50.3 \mathrm{MHz}, \mathrm{CDCl}_{3}\right)$ [HMQC allowed assignments of protonated carbons].

\begin{tabular}{|c|c|c|c|c|c|}
\hline $\mathrm{H}$ & 7 & 11 & $\mathrm{C}$ & 7 & 15 \\
\hline 1 & $4.97 d d(8.7 / 9.1)$ & $5.74 d d(10.8 / 17.0)$ & 1 & 131.1 & 77.1 \\
\hline $2 \mathrm{a}$ & $2.30-2.10 \mathrm{~m}$ & $5.03 d(10.8)$ & 2 & 27.4 & 27.8 \\
\hline $2 b$ & $2.30-2.10 \mathrm{~m}$ & $4.99 d(17.0)$ & 3 & 35.4 & 24.0 \\
\hline $3 \mathrm{a}$ & $2.55 d d d(2.9 / 7.5 / 11.6)$ & $5.39 s$ & 4 & 145.7 & 48.5 \\
\hline $3 b$ & 1.97 ddd (6.6/11.2/11.6) & $4.95 s$ & 5 & 130.1 & 50.8 \\
\hline 5 & $4.81 d(9.5)$ & $2.56 d(11.6)$ & 6 & 78.9 & 70.9 \\
\hline 6 & $4.99 d d(7.9 / 9.1)$ & $4.23 t(11.6)$ & 7 & 54.2 & 55.9 \\
\hline 7 & $3.06 \mathrm{~m}$ & $2.94 t t(2.9 / 11.2)$ & 8 & 74.8 & 70.5 \\
\hline 8 & 5.14 br $d d(8.3 / 9.1)$ & $5.26 \mathrm{td}(3.7 / 11.2)$ & 9 & 48.9 & 41.3 \\
\hline $9 \mathrm{a}$ & 2.52 br $d(12.0)$ & $1.65 d d(11.6 / 12.4)$ & 10 & 133.0 & 38.8 \\
\hline $9 b$ & 2.47 br $d d(11.2 / 12.0)$ & $2.02 d d(4.2 / 12.8)$ & 11 & 137.6 & 137.2 \\
\hline $13 \mathrm{a}$ & $6.25 d(2.9)$ & $6.12 d(2.9)$ & 12 & 167.5 & 166.9 \\
\hline $13 b$ & $5.76 d(2.5)$ & $5.57 d(2.9)$ & 13 & 125.9 & 129.3 \\
\hline 14 & $1.48 s$ & $1.15 \mathrm{~s}$ & 14 & 17.4 & 12.0 \\
\hline $15 \mathrm{a}$ & $4.28 d(14.1)$ & $4.05 d(13.7)$ & 15 & 61.1 & 202.7 \\
\hline $15 b$ & $4.06 d(14.1)$ & $3.98 d(13.7)$ & $1^{\prime}$ & 172.5 & 165.2 \\
\hline $3^{\prime}$ & $6.99 t(5.8)$ & $6.99 t(5.8)$ & $2^{\prime}$ & 133.7 & 139.1 \\
\hline $4^{\prime}$ & $4.46 d(5.8)$ & $4.45 d(5.8)$ & $3^{\prime}$ & 147.2 & 62.3 \\
\hline \multirow[t]{3}{*}{$5^{\prime}$} & $4.36 s$ & $4.38 \mathrm{~s}$ & $4^{\prime}$ & 59.7 & 125.9 \\
\hline & & & $5^{\prime}$ & 57.0 & - \\
\hline & & & $\mathrm{OOCH}_{3}$ & - & 52.1 \\
\hline
\end{tabular}

which showed coupling with the signal of $\mathrm{H}-5$ $(\delta$ 4.81) and H-7 ( $\delta$ 3.06). From the two doublets for $\mathrm{H}-13$ and $\mathrm{H}-13^{\prime}$ at $\delta 6.25(J=2.9 \mathrm{~Hz})$ and 5.76 $(J=2.5 \mathrm{~Hz})$, which showed coupling with $\mathrm{H}-7$, an $\alpha$-methylene- $\gamma$-lactone was also evident $\left[1760 \mathrm{~cm}^{-1}\right.$ in the IR spectrum; a methylene at $\delta 137.6(\mathrm{C}-11)$ and $125.9(\mathrm{C}-13)$ in the ${ }^{13} \mathrm{C}$ NMR $]$. An ester moiety was located at $\mathrm{C}-8 \alpha(\delta 74.8)$ as was deduced from the position and pattern of the signal at $\delta 5.14$ ( $b r d d, J=8.3$ and 9.1). The identity of the ester side chain was inferred from a two-proton singlet at $\delta 4.36$, and a doublet at $\delta 4.46(2 \mathrm{H}, J=$ $5.8 \mathrm{~Hz})$, which was coupled to a triplet at $\delta 6.99$ $(1 \mathrm{H})$. The chemical shifts and the pattern of these signals strongly suggested the presence of a 4,5dihydroxytiglate moiety (de Hernández et al., 1999). This was confirmed by the signals at $\delta 167.5$ (C), $133.7(\mathrm{C}), 147.2(\mathrm{CH}), 59.7\left(\mathrm{CH}_{2}\right)$ and 57.0 $\left(\mathrm{CH}_{2}\right)$ in the ${ }^{13} \mathrm{C}$ NMR spectrum (de Hernández et al., 1999), and the peaks at $\mathrm{m} / z 247[\mathrm{M}-$ $\mathrm{C}_{5} \mathrm{H}_{7} \mathrm{O}_{4}, \mathrm{M}-\mathrm{RCOO}^{+}$and $\mathrm{m} / z \quad 131 \quad\left[\mathrm{C}_{5} \mathrm{H}_{7} \mathrm{O}_{4}\right.$, $\mathrm{RCOO}^{+}$in the mass spectrum. Consequently, 7 is the new $8 \alpha$-(4,5-dihydroxytigloyloxy)-salonitenolide.

The ${ }^{1} \mathrm{H}$ NMR spectrum of compound 11 (Table I) showed typical low-field signals that clearly indicated the presence of an elemanolide, and ex- hibited common features with those of compound 10, an $8 \alpha$-acyl derivative of 11,13-dehydromelitensin (Cardona et al., 1989). Its mass spectrum presented peaks which suggested the same molecular mass and acyl side chain than compound $7(\mathrm{~m} / \mathrm{z}$ $378[\mathrm{M}]^{+}, m / z 247[\mathrm{M}-\mathrm{RCOO}]^{+}$and $\mathrm{m} / z 131$ $[\mathrm{RCOO}]^{+}$), and its structure was elucidated by the analysis of the ${ }^{1} \mathrm{H}$ NMR spectrum. The signals at $\delta 5.74 d d, 5.03 d, 4.99 d, 5.39 s$ and $4.95 s$ were assigned to $\mathrm{H}-1, \mathrm{H}-2 \mathrm{a}, \mathrm{H}-2 \mathrm{~b}, \mathrm{H}-3 \mathrm{a}$ and $\mathrm{H}-3 \mathrm{~b}$, respectively. An $\alpha$-methylene- $\gamma$-lactone was evident for the two doublets for $\mathrm{H}-13$ at $\delta 6.12$ and 5.57 which showed coupling $(J=2.9 \mathrm{~Hz})$ with the triplet of triplets at $\delta 2.94$ for H-7. A typical doublet at $\delta 2.56(J=11.6 \mathrm{~Hz})$ for $\mathrm{H}-5$, the signal at $\delta 4.23(t, J=11.6 \mathrm{~Hz})$ for $\mathrm{H}-6$ and the lowfield double triplet at $\delta 5.26$ corresponding to $\mathrm{H}-8$ indicated a trans-disposition of $\mathrm{H}-5 / \mathrm{H}-6, \mathrm{H}-6 / \mathrm{H}-7$ and $\mathrm{H}-7 / \mathrm{H}-8$ and so the oxygenated functions at C-6 and $\mathrm{C}-8$ should be $\alpha$-oriented. From a pair of doublets at $\delta 4.05$ and 3.98 a hydroxymethyl group as substituent at C-4 was also evident. The identity of the ester side chain was deduced from the chemical shifts of its protons, almost identical to those of compound 7. We have assigned to compound 11 the structure of the new $8 \alpha$-(4, 5-dihydroxytigloyloxy)-11,13-dehydromelitensin. 
C. achaia is characterised by the total absence of guaianolides, common metabolites of other Centaurea species (Fraga, 1992; 1993; 1994; 1995; 1996; 1997; 1998; 1999).

When its chemical profile is compared to previously studied Centaurea sp. belonging to the same section, appears quite deviating, as their main constituents are guaianolides: C. clementei (González et al., 1986); C. nicolai (Vajs et al., 1999), C. ornata (Navarro et al., 1990); C. ornata subsp. ornata (Bastos et al., 1994); C. ragustina subsp. ragustina (Mahmoud et al., 1986); C. salonitana (Daniewski et al., 1992; Daniewski et al., 1993).

Moreover, our results indicate that $C$. achaia comes close to many Onopordum species (Fraga; 1992; 1993; 1994; 1995; 1996; 1997; 1998; 1999), whose main compounds are onopordopicrin and closely related sesquiterpene lactones.

Compound $\mathbf{7}$ and onopordopicrin (2) were found to be the principal constituents of the lactone mixture, but both of them decompose rapidly.

All the tested compounds possess great antifungal activity. From the observed results (Table II), the lowest minimum inhibitory concentrations $(\mathrm{nmol} / \mathrm{ml})$, which inhibited the fungal growth, and the minimum fungicidal concentrations $(\mathrm{nmol} / \mathrm{ml})$, which killed the fungi, are for compounds $\mathbf{3}$ and $\mathbf{2}$, while compound $\mathbf{1 5}$ showed the greatest MICs and MFCs values, so, it possesses the lowest antifungal potential. MICs and MFCs for all tested compounds except 15 are $0.1-3.0$ and $0.75-6.0 \mathrm{nmol} /$ $\mathrm{ml}$, respectively, while MICs and MFCs for miconazole are $0.06-4.0$ and $4.0-10.0 \mathrm{nmol} / \mathrm{ml}$, indicating that most compounds investigated possessed greater antifungal potential as this commercial fungicide, which was used as a control (Table II). Penicillium ochrochloron, P. funiculosum and Trichoderma viride were the most resistant fungal species. It can be seen (Table II) that germacranolides $(\mathbf{2}-\mathbf{4}, \mathbf{7}, \mathbf{8})$ possess greater antifungal potential than the other groups, elemanolides $(\mathbf{1 0}, \mathbf{1 1})$ eudesmanolides $(\mathbf{1 3}, \mathbf{1 4})$ and the hydroxyester derivatives $(\mathbf{1 2}, \mathbf{1 5})$.

The biological activity of sesquiterpene lactones is generally attributed to the alkylating property of the $\alpha$-methylene- $\gamma$-lactone moiety, and the presence of other alkylating sites (epoxides and conjugated carbonyl groups) may enhance their biological activities. Moreover, their lipophilicity values seem to play an important role in antifungal activity (Inoue et al., 1995; Barrero et al., 2000). Since the chemical composition of the fungal cell walls is highly lipophilic, they generally represent strong barriers for the penetration of hydrophobic compounds, and the transport of polar compounds through the outer lipid layer of fungi is retarded. Our results support the hypothesis of an inverse relationship between polarity and antifungal activ-

Table II. Minimum inhibitory concentrations (MICs, nmol/ml) and minimum fungicidal concentrations (MFCs, $\mathrm{nmol} / \mathrm{ml}$ ) of different compounds.

\begin{tabular}{|c|c|c|c|c|c|c|c|c|c|c|c|c|}
\hline Micromycetes & $\begin{array}{l}2 \\
\mathrm{MIC} \\
(\mathrm{MFC})\end{array}$ & $\begin{array}{l}3 \\
\text { MIC } \\
(\mathrm{MFC})\end{array}$ & $\begin{array}{l}4 \\
\mathrm{MIC} \\
(\mathrm{MFC})\end{array}$ & $\begin{array}{l}7 \\
\text { MIC } \\
(\mathrm{MFC})\end{array}$ & $\begin{array}{l}8 \\
\mathrm{MIC} \\
(\mathrm{MFC})\end{array}$ & $\begin{array}{l}10 \\
\mathrm{MIC} \\
(\mathrm{MFC})\end{array}$ & $\begin{array}{l}11 \\
\text { MIC } \\
(\mathrm{MFC})\end{array}$ & $\begin{array}{l}12 \\
\text { MIC } \\
(\mathrm{MFC})\end{array}$ & $\begin{array}{l}13 \\
\text { MIC } \\
(\mathrm{MFC})\end{array}$ & $\begin{array}{l}14 \\
\text { MIC } \\
(\mathrm{MFC})\end{array}$ & $\begin{array}{l}15 \\
\mathrm{MIC} \\
(\mathrm{MFC})\end{array}$ & $\begin{array}{l}\text { Miconazole } \\
\text { MIC } \\
(\text { MFC) }\end{array}$ \\
\hline A. niger & $\begin{array}{c}0.1 \\
(0.75)\end{array}$ & $\begin{array}{c}0.4 \\
(0.75)\end{array}$ & $\begin{array}{c}0.4 \\
(0.75)\end{array}$ & $\begin{array}{c}0.4 \\
(0.75)\end{array}$ & $\begin{array}{c}0.5 \\
(1.0)\end{array}$ & $\begin{array}{c}0.4 \\
(0.75)\end{array}$ & $\begin{array}{c}0.4 \\
(0.75)\end{array}$ & $\begin{array}{c}0.4 \\
(1.5)\end{array}$ & $\begin{array}{r}0.75 \\
(1.5)\end{array}$ & $\begin{array}{c}0.4 \\
(0.75)\end{array}$ & $\begin{array}{c}1.5 \\
(3.0)\end{array}$ & $\begin{array}{c}3.0 \\
(8.0)\end{array}$ \\
\hline A. ochraceus & $\begin{array}{c}0.1 \\
(0.75)\end{array}$ & $\begin{array}{c}0.2 \\
(0.4)\end{array}$ & $\begin{array}{c}0.4 \\
(1.5)\end{array}$ & $\begin{array}{c}0.4 \\
(0.75)\end{array}$ & $\begin{array}{c}0.5 \\
(2.0)\end{array}$ & $\begin{array}{c}0.4 \\
(0.75)\end{array}$ & $\begin{array}{c}0.4 \\
(0.75)\end{array}$ & $\begin{array}{c}0.4 \\
(1.5)\end{array}$ & $\begin{array}{r}0.75 \\
(1.5)\end{array}$ & $\begin{array}{c}0.4 \\
(0.75)\end{array}$ & $\begin{array}{c}1.5 \\
(3.0)\end{array}$ & $\begin{array}{c}3.0 \\
(8.0)\end{array}$ \\
\hline A. versicolor & $\begin{array}{c}0.4 \\
(1.5)\end{array}$ & $\begin{array}{c}0.2 \\
(0.4)\end{array}$ & $\begin{array}{r}0.75 \\
(1.5)\end{array}$ & $\begin{array}{l}1.5 \\
(1.5)\end{array}$ & $\begin{array}{c}2.0 \\
(4.0)\end{array}$ & $\begin{array}{l}1.5 \\
(1.5)\end{array}$ & $\begin{array}{c}1.5 \\
(3.0)\end{array}$ & $\begin{array}{r}0.75 \\
(1.5)\end{array}$ & $\begin{array}{c}1.5 \\
(3.0)\end{array}$ & $\begin{array}{r}0.75 \\
(1.5)\end{array}$ & $\begin{array}{c}3.0 \\
(6.0)\end{array}$ & $\begin{array}{c}4.0 \\
(8.0)\end{array}$ \\
\hline A. flavus & $\begin{array}{c}0.4 \\
(1.5)\end{array}$ & $\begin{array}{c}0.4 \\
(0.75)\end{array}$ & $\begin{array}{r}0.75 \\
(1.5)\end{array}$ & $\begin{array}{c}0.4 \\
(0.75)\end{array}$ & $\begin{array}{l}1.0 \\
(2.0)\end{array}$ & $\begin{array}{r}0.75 \\
(1.5)\end{array}$ & $\begin{array}{l}1.5 \\
(3.0)\end{array}$ & $\begin{array}{r}0.75 \\
(1.5)\end{array}$ & $\begin{array}{l}1.5 \\
(3.0)\end{array}$ & $\begin{array}{r}0.75 \\
(1.5)\end{array}$ & $\begin{array}{c}6.0 \\
(12.0)\end{array}$ & $\begin{array}{l}1.0 \\
(8.0)\end{array}$ \\
\hline P.ochrochloron & $\begin{array}{r}0.75 \\
(1.5)\end{array}$ & $\begin{array}{c}0.75 \\
(0.75)\end{array}$ & $\begin{array}{c}1.5 \\
(3.0)\end{array}$ & $\begin{array}{c}0.4 \\
(1.5)\end{array}$ & $\begin{array}{l}2.0 \\
(4.0)\end{array}$ & $\begin{array}{r}0.75 \\
(1.5)\end{array}$ & $\begin{array}{c}1.5 \\
(3.0)\end{array}$ & $\begin{array}{r}0.75 \\
(1.5)\end{array}$ & $\begin{array}{c}3.0 \\
(6.0)\end{array}$ & $\begin{array}{l}1.5 \\
(3.0)\end{array}$ & $\begin{array}{c}6.0 \\
(12.0)\end{array}$ & $\begin{array}{c}2.0 \\
(10.0)\end{array}$ \\
\hline P. funiculosum & $\begin{array}{l}1.5 \\
(3.0)\end{array}$ & $\begin{array}{c}0.75 \\
(1.5)\end{array}$ & $\begin{array}{l}1.5 \\
(3.0)\end{array}$ & $\begin{array}{l}1.5 \\
(3.0)\end{array}$ & $\begin{array}{l}2.0 \\
(4.0)\end{array}$ & $\begin{array}{l}1.5 \\
(1.5)\end{array}$ & $\begin{array}{l}3.0 \\
(6.0)\end{array}$ & $\begin{array}{r}0.75 \\
(1.5)\end{array}$ & $\begin{array}{c}3.0 \\
(6.0)\end{array}$ & $\begin{array}{c}1.5 \\
(3.0)\end{array}$ & $\begin{array}{c}6.0 \\
(12.0)\end{array}$ & $\begin{array}{c}4.0 \\
(10.0)\end{array}$ \\
\hline T. viride & $\begin{array}{c}1.5 \\
(3.0)\end{array}$ & $\begin{array}{r}0.75 \\
(1.5)\end{array}$ & $\begin{array}{c}1.5 \\
(3.0)\end{array}$ & $\begin{array}{r}0.75 \\
(3.0)\end{array}$ & $\begin{array}{c}2.0 \\
(4.0)\end{array}$ & $\begin{array}{l}1.5 \\
(1.5)\end{array}$ & $\begin{array}{c}3.0 \\
(6.0)\end{array}$ & $\begin{array}{c}1.5 \\
(3.0)\end{array}$ & $\begin{array}{c}3.0 \\
(6.0)\end{array}$ & $\begin{array}{l}1.5 \\
(3.0)\end{array}$ & $\begin{array}{c}6.0 \\
(12.0)\end{array}$ & $\begin{array}{c}4.0 \\
(4.0)\end{array}$ \\
\hline C. cladosporioides & $\begin{array}{c}0.4 \\
(0.75)\end{array}$ & $\begin{array}{c}0.4 \\
(0.75)\end{array}$ & $\begin{array}{r}0.75 \\
(1.5)\end{array}$ & $\begin{array}{r}0.75 \\
(1.5)\end{array}$ & $\begin{array}{l}1.0 \\
(2.0)\end{array}$ & $\begin{array}{c}0.4 \\
(0.75)\end{array}$ & $\begin{array}{r}0.75 \\
(1.5)\end{array}$ & $\begin{array}{c}0.4 \\
(1.5)\end{array}$ & $\begin{array}{r}0.75 \\
(1.5)\end{array}$ & $\begin{array}{r}0.75 \\
(1.5)\end{array}$ & $\begin{array}{c}1.5 \\
(3.0)\end{array}$ & $\begin{array}{c}0.06 \\
(0.06)\end{array}$ \\
\hline A. alternata & $\begin{array}{c}0.75 \\
(1.5)\end{array}$ & $\begin{array}{r}0.75 \\
(1.5)\end{array}$ & $\begin{array}{c}1.5 \\
(1.5)\end{array}$ & $\begin{array}{r}0.75 \\
(1.5)\end{array}$ & $\begin{array}{c}1.0 \\
(2.0)\end{array}$ & $\begin{array}{c}0.75 \\
(1.5)\end{array}$ & $\begin{array}{r}0.75 \\
(1.5)\end{array}$ & $\begin{array}{c}0.75 \\
(1.5)\end{array}$ & $\begin{array}{r}0.75 \\
(1.5)\end{array}$ & $\begin{array}{r}0.75 \\
(1.5)\end{array}$ & $\begin{array}{r}0.75 \\
(1.5)\end{array}$ & $\begin{array}{c}1.0 \\
(1.0)\end{array}$ \\
\hline
\end{tabular}


ity for sesquiterpene lactones in general (Barrero et al., 2000), since, regarding the retention times of our compounds on a RP-18 column, their polarity is decreasing from eudesmanolides $>$ elemanolides $>$ germacranolides.

\section{Experimental}

\section{Plant material}

Aerial parts of Centaurea achaia Boiss. \& Heldr. were collected on Mount Pateras (Attiki - central Greek mainland), in June 1994 and authenticated by Dr. Th. Constantinidis (Institute of Systematic Botany, University of Patras). A voucher specimen is deposited in the Herbarium of the above-mentioned Institute under the number Constantinidis 2180 (UPA).

\section{Extraction and isolation}

The fresh plant material $(2.0 \mathrm{~kg})$ was finely ground and extracted at room temp. with cyclohexane $-\mathrm{Et}_{2} \mathrm{O}-\mathrm{MeOH}(1: 1: 1 \mathrm{v} / \mathrm{v})$. The extract was washed with brine, the aq. layer re-extracted with EtOAc, and the organic layer dried with $\mathrm{Na}_{2} \mathrm{SO}_{4}$ and concd. under red. pressure. The residue $19.3 \mathrm{~g}$ was prefractionated by VLC on silica gel, using cyclohexane-EtOAc- $\mathrm{Me}_{2} \mathrm{CO}$ mixts. of increasing polarity as eluents to give several frs. Frs B (hexane-EtOAc, 1:1 v/v), C (hexane-EtOAc, 1:4 v/v), $\mathrm{D}(\mathrm{EtOAc})$ and $\mathrm{E}(\mathrm{EtOAc}-$ acetone, $4: 1 \mathrm{v} / \mathrm{v})$ were subjected to further chromatographic separations as described below.

$\mathrm{CC}$ of fr B $\left(\mathrm{CH}_{2} \mathrm{Cl}_{2}-\mathrm{MeOH}, 10: 0\right.$ to $\left.9: 1 \mathrm{v} / \mathrm{v}\right)$ followed by HPLC $\left(\mathrm{MeOH}-\mathrm{H}_{2} \mathrm{O}, 3: 2\right)$ allowed the isolation of $5(3.9 \mathrm{mg})$. VLC of fr $\mathrm{C}\left(\mathrm{CH}_{2} \mathrm{Cl}_{2}-\right.$ $\mathrm{MeOH}, \quad 10: 0$ to $1: 1 \mathrm{v} / \mathrm{v})$ followed by HPLC $\left(\mathrm{MeOH}-\mathrm{H}_{2} \mathrm{O}, 2: 1\right.$ and $\left.4: 3 \mathrm{v} / \mathrm{v}\right)$ allowed the isolation of $\mathbf{2}(9.6 \mathrm{mg})$ and $\mathbf{1 0}(1.0 \mathrm{mg})$. CC of fr D $\left(\mathrm{CH}_{2} \mathrm{Cl}_{2}-\mathrm{MeOH}, 10: 0\right.$ to $\left.8: 2 \mathrm{v} / \mathrm{v}\right)$ followed by several HPLC $\left(\mathrm{MeOH}-\mathrm{H}_{2} \mathrm{O}, 3: 2,4: 3\right.$ and 1:1) allowed the isolation of $\mathbf{1}(20.4 \mathrm{mg})$, a mixt. of $\mathbf{1}$ and 8 (ca. $12.1 \mathrm{mg}$, not separated), 8 (14.0 mg), 2 (103.1 mg), 3 (42.8 mg), 4 (4.5 mg), 6 (5.2 mg), 9 (1.1 mg), $10(5.1 \mathrm{mg}), \mathbf{1 2}(17.2 \mathrm{mg}), \mathbf{1 3}(31.1 \mathrm{mg})$ and $14(4.3 \mathrm{mg})$. VLC of fr $\mathrm{E}\left(\mathrm{CH}_{2} \mathrm{Cl}_{2}-\mathrm{MeOH}\right.$, 10:0 to 7:3) followed by further CC and HPLC $\left(\mathrm{MeOH}-\mathrm{H}_{2} \mathrm{O}, 1: 1 \mathrm{v} / \mathrm{v}\right)$ allowed the isolation of 2 (4.8 mg), 7 (177.3 mg), 10 (1.9 mg), 12 (11.3 mg), $14(10.2 \mathrm{mg}), \mathbf{1 5}(11.5 \mathrm{mg}), \mathbf{1 1}(1.3 \mathrm{mg})$ and a mixt. of $\mathbf{7}$ and $\mathbf{1 1}$ ( $c a .12 .5 \mathrm{mg}$, not separated).

\section{Chromatography}

Vacuum liquid chromatography (VLC): silica gel (Merck; 43-63 $\mu \mathrm{m}$ ), CC: silica gel (SDS; 40-63 $\mu \mathrm{m})$, gradient elution with the solvents mixts indicated in each case; HPLC: CE 1100 Liquid Chromatography Pumb Techsil 10-C18 $(250 \times 10 \mathrm{~mm})$.

Absorbents for TLC: Merck RP $18 \mathrm{~F}_{254 \mathrm{~s}}$; Merck silica gel $60 \mathrm{~F}_{254 \mathrm{~s}}$; solvents for TLC: mixt. of $\mathrm{CH}_{2} \mathrm{Cl}_{2}$ with $\mathrm{MeOH}$; mixt. of cyclohexane with EtOAc. Detection on TLC-plates: UV-light, spray reagent (anisaldehyde $-\mathrm{H}_{2} \mathrm{SO}_{4}$ on silica gel).

\section{Spectroscopic data}

NMR: $400 \mathrm{MHz}$ (1D and 2D), $200 \mathrm{MHz}\left({ }^{1} \mathrm{H}\right)$ and $50.3 \mathrm{MHz}\left({ }^{13} \mathrm{C}\right)$. The NMR spectra were recorded using Bruker Avance 400 and Bruker AC 200. Chemical shifts are reported in $\delta(\mathrm{ppm})$ values. MS: Hewlett-Packard mod. 5973; 70eV. FTIR Spectrometer: Perkin-Elmer Paragon 500. Polarimeter: Perkin-Elmer 341. The optical rotation values were determined at $25^{\circ} \mathrm{C}$ at $589 \mathrm{~nm}$ in $\mathrm{CHCl}_{3}$ (Uvasol).

Compound 7: Unstable colorless oil; $[\alpha]_{\mathrm{D}}^{20}+0.18^{\circ}$ $\left(\mathrm{CHCl}_{3} \mathrm{c}, 2.84\right)$; IR $v_{\max }^{\mathrm{KBr}} \mathrm{cm}^{-1}: 3600-3300,1750$, 1720; EIMS $m / z$ (rel.int.): $378[\mathrm{M}]^{+}$(3), 247 [MFO $]^{+}(10), 131[\mathbf{F O}]^{+}(30) .{ }^{1} \mathrm{H}$ NMR and ${ }^{13} \mathrm{C}$ NMR spectral data: see Table I.

Compound 11: Colorless oil; $[\alpha]_{\mathrm{D}}^{20}+19.6^{\circ}\left(\mathrm{CHCl}_{3}\right.$ c, 0.09); IR $v_{\max }^{\mathrm{KBr}} \mathrm{cm}^{-1}: 3600-3300,1760,1710,1640$; EIMS $\mathrm{m} / z$ (rel.int.): $378[\mathrm{M}]^{+}(5), 350[\mathrm{M}-\mathrm{CO}]^{+}$

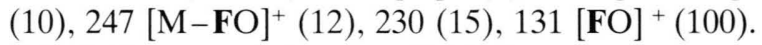
${ }^{1} \mathrm{H}$ NMR spectral data: see Table I.

\section{Bioassays}

For the bioassays nine fungi were used: Aspergillus niger (ATCC 6275), Aspergillus ochraceus (ATCC 12066), Aspergillus versicolor (ATCC 11730), Aspergillus flavus (ATCC 9643), Penicillium ochrochloron (ATCC 9112), Penicillium funiculosum (ATCC 36839), Trichoderma viride (IAM 5061), Cladosporium cladosporioides (ATCC 13276) and Alternaria alternata (DSM 2006).

The organisms were obtained from the Mycological Laboratory, Department of Plant Physiology, Institute for Biological research "Sinisa Stankovic", Belgrade, Yugoslavia.

The micromycetes were maintained on malt agar (MA) and the cultures were stored at $+4^{\circ} \mathrm{C}$ and subcultured once a month (Booth, 1971). 
In order to investigate the antifungal activity of 11 compounds the modified microdilution technique was used (Hanel and Raether, 1988; Daouk et al.,1995). The fungal spores were washed from the surface of agar plates with sterile $0.85 \%$ saline containing $0.1 \%$ Tween 80 ( $\mathrm{vol} / \mathrm{vol})$. The spore suspension was adjusted with sterile saline to a concentration of approximately $1.0 \times 10^{5}$ in a final volume of $100 \mu \mathrm{l}$ per well. The inocula were stored at $+4{ }^{\circ} \mathrm{C}$ for further use. Dilutions of the inocula were cultured on solid MA to verify the absence of contamination and to check the validity of the inoculum.

Minimum inhibitory concentrations (MICs) determination was performed by a serial dilution technique using 96-well microtitre plates. Extracts

Bastos M. M. S. M., Kijjoa A. and Pinto M. M. M. (1994), Lignans and other constituents of Centaurea ornata ssp. ornata. Fitoterapia 65, 191.

Booth C. (1971), Fungal Culture Media. In: Methods in Microbiology, 4th ed. (J. R. Norris and D. W. Ribbons eds.). Academic Press, London \& New York, pp. 4994.

Cardona M. L., Garcia B., Pedro J. R. and Sinisterra J. F. (1989), Sesquiterpene lactones and an elemane derivative from Onopordon corymbosum. Phytochemistry 28, $1264-1267$.

Cardona M. L., Garcia B., Muñoz M. C., Navarro F. I. and Pedro J. R. (1997), New sesquiterpenes and other constituents from Centaurea paui. Liebigs Ann./Recl. 3, $527-532$.

Daniewski W. M., Nowak G., Routsi E., Rychlewska U., Szczepanska B. and Skibicki P. (1992), Salograviolide A, a sesquiterpene from Centaurea salonitana. Phytochemistry 31, 2891-2893.

Daniewski W. M., Nowak G., Pankowska E., Georgiadis T., Routsi E., Rychlewska U. and Szczepanska B. (1993), Sesquiterpene lactones of Centaurea salonitana. Phytochemistry 34, 445-447.

Daouk R. K., Dagher S. M. and Sattout E. J. (1995), Antifungal activity of the essential oil of Origanum syriacum L. J. Food Prot. 58, 1147-1149.

El-Masry S., Darwisch F. A., Abou-Donia A., AbouKaram M. A. and Grenz M. (1985), Sesquiterpene lactones from Centaurea glomerata. Phytochemistry 24, 999-1001.

Fraga B. M., (1992; 1993; 1994; 1995; 1996; 1997; 1998; 1999), Natural sesquiterpenoids. Natural Products Reports, 9, 217-241 and 557-580; 10, 397-419; 11, 533$554 ; \mathbf{1 2}, 303-320 ; \mathbf{1 3}, 307-326 ; \mathbf{1 4}, 145-162 ; \mathbf{1 5}, 73-$ $92 ; \mathbf{1 6}, 21-38$.

González C. I., Macias F. A., Massanet G. M. and Rodrigez L. F. (1986), Structure, chemistry and stereochemistry of clementeins sesquiterpene lactones from Centaurea clementei. Tetrahedron 42, 3611-3622.

Hanel H. and Raether W. (1988), A more sophisticated method of determining the fungicidal effect of water- of compounds investigated were dissolved in malt medium broth with fungal inoculum to achieve concentrations of $0.1-12.0 \mathrm{nmol} / \mathrm{ml}$. The microplates were incubated for $72 \mathrm{~h}$ at $28^{\circ} \mathrm{C}$. The lowest concentrations without visible growth (at the binocular microscope) was defined as concentrations which completely inhibited fungal growth (MICs). The minimum fungicidal concentrations (MFCs) was determined by serial subcultivation of a $2 \mu \mathrm{l}$ into microtitre plates containing $100 \mu \mathrm{l}$ of broth per well and further incubation for $72 \mathrm{~h}$ at $28^{\circ} \mathrm{C}$. The lowest concentration with no visible growth was defined as the MFC, indicating $=99.5 \%$ killing rate of the original inoculum. Miconazole, a commercial fungicide, was used as a control (0.06$10.0 \mathrm{nmol} / \mathrm{ml})$.

insoluble preparations with a cell harvester, using miconazole as an example. Mycoses. 31, 148-154.

de Hernandez Z. N. J., Catalan C. A. N., Hernandez L. R. and Guerra-Ramirez D. (1999), Sesquiterpene lactones from Stevia alpina var. glutinosa. Phytochemistry $\mathbf{5 1}, 79-82$.

Inoue A., Tamogami S., Kato H., Nakazato Y., Akiyama M., Kodama O., Akatsuka T. and Hashidoko Y. (1995), Antifungal melampolides from leaf extracts of Smallanthus sonchifolius. Phytochemistry 39, 845848.

Lazari D., Garcia B., Skaltsa E., Pedro J. R. and Harvala C. (1998), Sesquiterpene lactones from Onopordon laconicum and $O$. sibthorpianum. Phytochemistry 47, $415-422$.

Mabberley D. J. (1997), The Plant Book, 2nd edition, Cambridge University Press, Cambridge, U.K., p. 138.

Mahmoud Z. F., Kasem, F. F. and Abdel-Salam N. M. (1986), Sesquiterpene lactones and flavonoids of Centaurea ragustina ssp. ragustina growing in Egypt. Egypt J. Pharm. Sci., 27, 283-290. BIOSIS: 84049287. Marco J. A., Sanz-Cervera J. F., Sancenon F., Susanna A., Rustaiyan A. and Saberi M. (1992), Sesquiterpene lactones and lignans from Centaurea species. Phytochemistry 31, $3527-3530$.

Navarro J. J., Caballero M. C., Moran J. R., Medarde M., Grande M. and Anaya J. (1990), Guaianolides and eudesmanolides from Centaurea ornata. J. Nat. Prod. 53, $573-578$.

Rustaiyan A., Ahmadi B., Jacupovic J. and Bohlmann F. (1986), Sesquiterpene lactones and eudesmane derivatives from Onopordon carmanicum. Phytochemistry 25, 1659-1662.

Skaltsa H., Lazari D., Georgiadou E., Kakavas S. and Constantinidis Th. (1999), Sesquiterpene Lactones from Centaurea Species: C. thessala subsp. drakiensis and $C$. attica subsp. attica. Planta Med. 65, 393.

Vajs V., Todorovic N., Ristic M., Teševic V., Todorovic, B., Janackovic P., Marin P. and Milosavljevic S. (1999), Guaianolides from Centaurea nicolai: antifungal activity. Phytochemistry 52, 383-386. 